Hydrol. Earth Syst. Sci., 13, 1739-1747, 2009

www.hydrol-earth-syst-sci.net/13/1739/2009/

(c) Author(s) 2009. This work is distributed under

the Creative Commons Attribution 3.0 License.

\title{
Simulating past droughts and associated building damages in France
}

\author{
T. Corti ${ }^{1}$, V. Muccione $^{2}$, P. Köllner-Heck ${ }^{2}$, D. Bresch ${ }^{2}$, and S. I. Seneviratne ${ }^{1}$ \\ ${ }^{1}$ Institute for Atmospheric and Climate Science, ETH Zurich, Zurich, Switzerland \\ ${ }^{2}$ Natural Catastrophes, Swiss Reinsurance Company, Zurich, Switzerland
}

Received: 13 January 2009 - Published in Hydrol. Earth Syst. Sci. Discuss.: 2 March 2009

Revised: 21 August 2009 - Accepted: 11 September 2009 - Published: 30 September 2009

\begin{abstract}
Droughts can induce important building damages due to shrinking and swelling of soils, leading to costs as large as for floods in some regions. Previous studies have focused on damage data analysis, geological or constructional aspects. Here, a study investigating the climatic aspects of soil subsidence damage is presented for the first time. We develop a simple model to examine if the meteorology has a considerable impact on the interannual variability of damages from soil subsidence in France. We find that the model is capable of reproducing yearly drought-induced building damages for the time period 1989-2002, thus suggesting a strong meteorological influence. Furthermore, our results reveal a doubling of damages in these years compared to 19611990, mainly as a consequence of increasing temperatures. This indicates a link to climate change. We also apply the model to the extreme summer of 2003, which caused a further increase in damage by a factor four, according to a preliminary damage estimate. The simulation result for that year shows strong damage underestimation, pointing to additional sources of vulnerability. Damage data suggest a higher sensitivity to soil subsidence of regions first affected by drought in the 2003 summer, possibly due to a lack of preparedness and adaptation. This is of strong concern in the context of climate change, as densely populated regions in Central Europe and North America are expected to become newly affected by drought in the future.
\end{abstract}

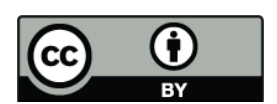

Correspondence to: T. Corti (thierry.corti@env.ethz.ch)

\section{Introduction}

Climate models project an enhanced occurrence of droughts in mid-latitude regions (e.g., Wang, 2005; Christensen et al., 2007; Sheffield and Wood, 2008), particularly in Europe (Seneviratne et al., 2006b; Gao and Giorgi, 2008) and Central North America (Seager et al., 2007). This could have majors impacts on human health (Haines et al., 2006), agriculture (Easterling et al., 2007) and water management (Schindler and Donahue, 2006; Milly et al., 2008). Moreover, changes in drought occurrence could also lead to increasing damages from soil subsidence.

Soil subsidence is a process by which certain soils shrink and swell in response to dry and wet conditions (Bronswijk, 1989). In France, soil subsidence has caused as much damage as floods in recent years (CCR, 2007). The large cost for society is contrasted by a general lack of concepts to assess the risk associated with this hazard. There are approaches available to simulate damages caused by other natural hazards such as floods (e.g., Dutta et al., 2003; Apel et al., 2006), winter storms (Klawa and Ulbrich, 2003) and landslides (Dai et al., 2002). However, such applications have not been attempted previously for drought-induced soil subsidence damages, since previous studies concerning this hazard have mainly focused on damage data analysis, geological or constructional aspects (e.g., Doornkamp, 1993; Plante, 1998; Crilly, 2001). The present study is thus a novel project developping a meteorologically-based modeling system for this hazard. In this article, we first introduce the phenomenon of soil subsidence in more detail. Then, we develop a simple model driven by meteorological observations to simulate damages from soil subsidence and investigate the impact of meteorology on the interannual variability of damages in France.

Published by Copernicus Publications on behalf of the European Geosciences Union. 


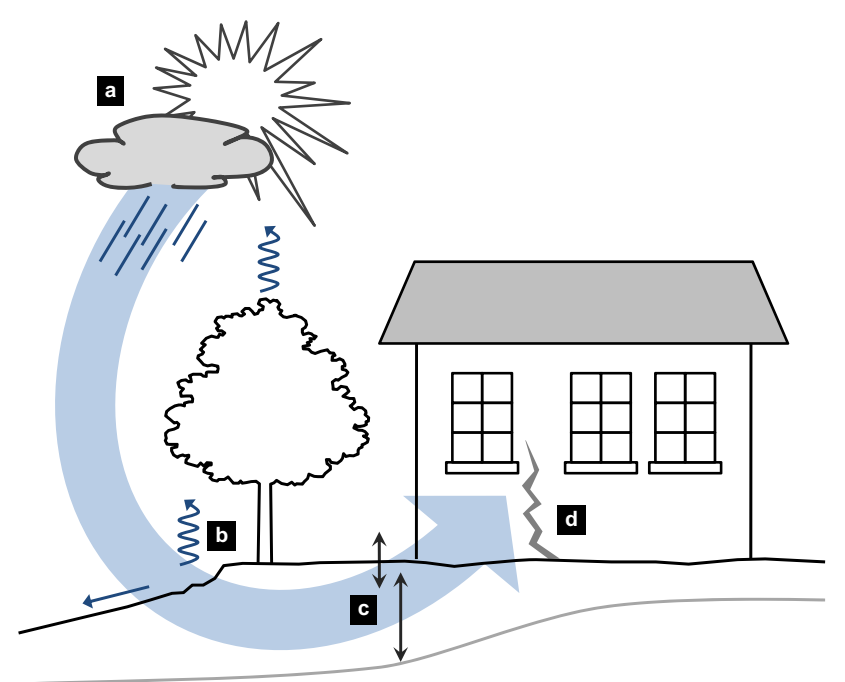

Fig. 1. Schematic of the impact chain leading to building damages from soil subsidence. Meteorology (a), soil hydrology (b), soil shrinkage and swelling (c), building damage (d).

\section{Drought-induced soil subsidence}

Soil subsidence can be understood through links between meteorology, soil hydrology, soil mechanics and building damage, as illustrated in Fig. 1. Meteorology (temperature, precipitation, and radiation) is the principal factor driving the soil water balance, which determines in turn the amount of water in the soil. Within the soil, soil type is an important factor in determining the extent of volume changes with changing soil water content (Boivin et al., 2006). Critical soil properties are, among others, soil depth, the fraction of swelling clays and the soil's ability to take up water. Combined, the soil properties determine the amount of vertical soil movement as the soil alternates between wet and dry conditions, potentially harming buildings or other infrastructure.

However, it appears that not all buildings are affected to the same extent by shrinking and swelling soils. A survey of damaged buildings in Great Britain (Crilly, 2001) has shown that detached buildings are more affected than others, and that the age of buildings and foundation depth can play a role. In this study, we will assume that the influence of regional differences in constructional aspects are negligible on the national level.

In France, the phenomenon of soil subsidence was first observed after the 1976 drought, when severe building structure failures occurred. After the 1989 drought, tens of thousands of residential buildings were affected (Salagnac, 2007). As a consequence, soil subsidence was integrated in the French natural catastrophes insurance system (CatNat). In addition, a geological risk assessment was initiated, led by the Bureau de Recherches Géologiques et Minières (BRGM). The amount of damage peaked in 2003, when the summer drought caused unprecedented damage of over 1000 Mio Euro according to a recent estimate (CCR, 2007).

Soil subsidence differs from other natural hazards such as floods, avalanches and landslides in several respects. First, as a drought-related hazard, soil subsidence develops on time scales of months. Second, the soil movement is generally not clearly evident, with typical vertical displacements in the range of centimeters (Plante, 1998). Third, the affected area is larger than for most other natural hazards. These special characteristics of soil subsidence implicate also that numerical models and simulation frameworks designed to quantify damages from floods (e.g., Dutta et al., 2003, Apel et al., 2006) and other natural hazards cannot be applied to soil subsidence.

\section{Employed datasets}

\subsection{Damage data - countrywide estimates}

Two estimates for soil subsidence damage in France have been obtained from the Caisse Centrale de Réassurance (CCR) and the Fédération Française des Sociétés d'Assurance (FFSA), covering the period 1989 to 2002 (Dumas et al., 2005). We use the mean values of the two datasets as best estimates. The data has been adjusted to the year 2000 based on the growth of Gross Domestic Product (GDP) and Consumer Price Index (CPI), in order to account for the increasing number of buildings and their value, respectively. The uncertainty range was determined as twice the mean difference between the two data sets and at most $30 \%$ of the reported value of one year. For the year 2003, a preliminary damage estimate is available from CCR (CCR, 2007).

The damage data represents the amount of compensations granted in cases when a declaration of state of natural disaster due to soil subsidence was issued by an interministerial decree. This means that the reported damage might contain an administrative or political component, which does not necessarily reflect the real magnitude of the event. It also implicates that the reported damage is attributed to a single event, facilitating its comparison to simulated damage.

\subsection{Damage data - departmental resolution}

In addition to the damage data on national level, anonymized data with departmental resolution was collected from several insurers by the Swiss Reinsurance Company. The data cover the years 1997 to 2003. Upscaling to the whole French market shows that the data is in good agreement with the values provided by CCR and FFSA. Within the departments, the damage data was disaggregated based on the population distribution. This data allows the detection of regional differences in the sensitivity to soil subsidence. 


\subsection{Meteorological data}

Monthly mean temperature and precipitation observations were obtained from two gridded data sets: CRU TS 2.1 (Mitchell and Jones, 2005) and E-obs (Haylock et al., 2008). The meteorological data was interpolated to a regular grid with 0.05 degrees resolution.

\subsubsection{Population distribution}

Population density data was obtained from the European Environment Agency Data Service and interpolated to derive the number of inhabitants on a 0.05 degrees spatial resolution.

\section{Model}

\subsection{Overview}

We simulate soil subsidence damages on a grid of 0.05 degrees resolution (i.e., 25400 grid points) with a soil model driven by meteorological observations in combination with an indicator-based loss model. The model approach is comparable to model frameworks for other natural hazards (e.g., winter storms, see Klawa and Ulbrich, 2003).

The soil subsidence damages are computed as follows. First, we use the soil model underlying the Palmer Drought Severity Index (PDSI) to compute the monthly water balance. A detailed description of this widely-used model (see e.g., Trenberth et al., 2007) can be found in Palmer (1965) and Weber and Nkemdirim (1998). In brief, we solve the equation

$W_{C} \frac{d \theta}{d t}=P-E-R$,

where $W_{C}$ is the water holding capacity, $\theta$ the relative soil moisture saturation, $E$ the evapotranspiration and $R$ the runoff. The precipitation $P$ is defined by the gridded precipitation observations. The evapotranspiration $E$ is equivalent to potential evapotranspiration (PET) according to Thornthwaite (1948) in case of saturated soil moisture conditions. The computation of PET requires temperature observations. Under unsaturated conditions, evapotranspiration is derived based on a precipitation-limited approach (see Weber and Nkemdirim, 1998). Runoff $R$ occurs when soil saturation is exceeded. The water holding capacity $W_{C}$ is the only free model parameter that needs specification. Finding the correct value for this parameter is difficult, which is also reflected in the largely variable specifications of land surface models (Seneviratne et al., 2006a). There are soil hydrological maps available, but these describe the properties of natural soils, whereas the soil structure surrounding buildings is essentially artificial. In the absence of better knowledge, we therefore assume a constant water holding capacity of $500 \mathrm{~mm}$, which is within the range of typical model values

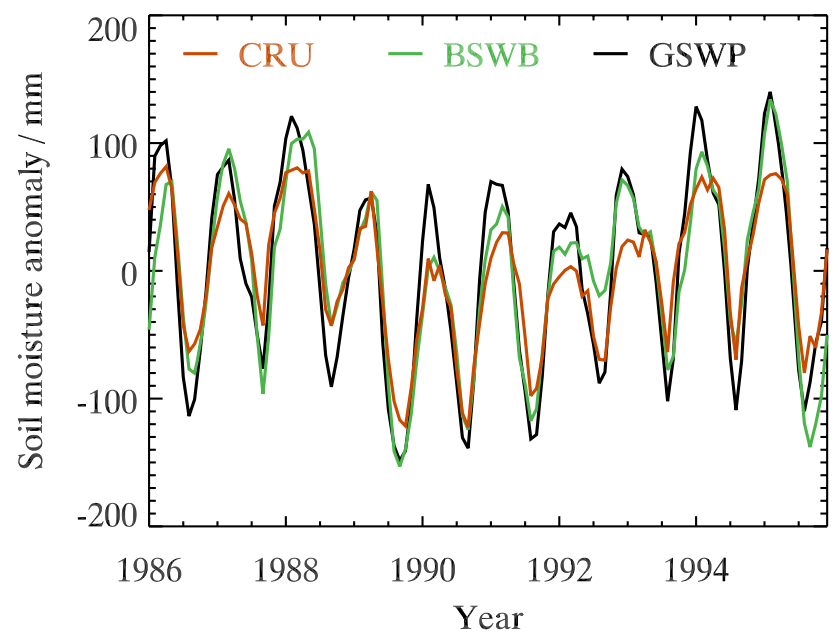

Fig. 2. Time series of the soil moisture anomaly averaged over the French domain (soil water content minus 10-year mean) from our simulation driven by CRU data in comparison with the multi-model analysis from the Global Soil Wetness Project 2 (GSWP-2) and the Basin-Scale Water-Balance (BSWB) data set.

(see e.g., Seneviratne et al., 2006a). Sensitivity experiments using different values or a soil hydrological map show little dependence of the results to the exact value of this parameter for this application (see Sect. 5.2). The water balance computations result in monthly estimates of the soil water content on a 0.05 degree resolution in France.

We verified the simulated soil water content by comparing it with the multi-model analysis from the Global Soil Wetness Project 2 (GSWP-2, Dirmeyer et al., 2006) and the Basin-Scale Water-Balance (BSWB, Seneviratne et al. (2004); Hirschi et al. (2006)) data set. Figure 2 shows time series of domain-averaged soil moisture anomalies in France. The model driven by CRU data agrees well with the two data sets, with coefficients of determination $\left(R^{2}\right)$ of 0.92 and 0.90 in comparison with GSWP and BSWB, respectively. Results from the simulations driven by E-obs (not shown) are very similar and have $R^{2}$ values of 0.93 and 0.90 .

We conclude that even though the PDSI water balance model is comparatively simple, its performance in simulating soil moisture content is respectable. It is however important to note that the model is limited to the description of the water balance only, whereas the land surface models participating in GSWP describe further components such as energy and tracer component fluxes. For the present application, we are interested in a simple drought indicator and the tested model appears thus well suited.

As a next step, the monthly soil moisture content is used to calculate the difference between the water holding capacity and the minimum annual soil water content (i.e., the annual soil moisture deficit $d$ ) as indicator for soil subsidence. This 


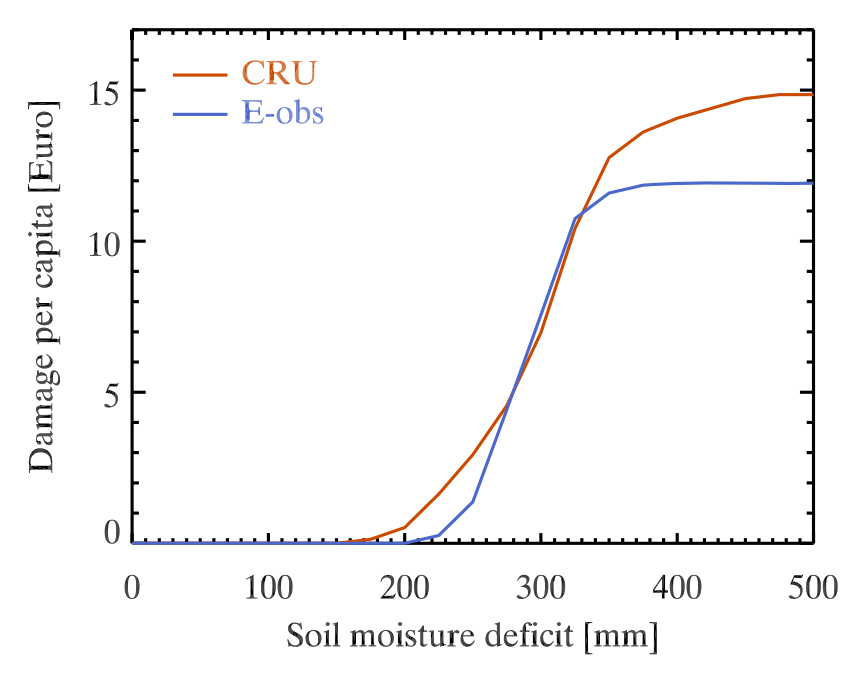

Fig. 3. Optimal vulnerability curves used to translate the soil moisture deficit to the damage per inhabitant for the simulations driven by CRU and E-obs meteorological data.

can also be written as

$d=W_{C}\left(1-\theta_{\min }\right)$,

where $\theta_{\min }$ is the minimum soil saturation of a specific year.

Thereon, the soil moisture deficit $d$ is translated into damage per capita based on a single empirical vulnerability curve (see Sect. 4.2) and multiplied with the population distribution to derive the annual damage at each grid cell. Only sparsely populated or entirely unpopulated areas (e.g., covered by forest and other natural surfaces) thus do not contribute to the simulated damage. Finally, the damage is totalized to the damage on national level by summarizing over all grid cells.

\subsection{Vulnerability curve}

In our model, a vulnerability curve is needed to translate the soil subsidence indicator to the damage degree expressed as damage per capita. This single vulnerability curve is applied at all grid points within the model domain, in line with our assumption that potential regional differences in the vulnerability of buildings to soil subsidence are negligible for the computation of damages on the national level.

There are no specific vulnerability curves for soil subsidence available, in contrast to other hazards, such as floods (see e.g., Dutta et al., 2003). For the present study, we therefore derive empirical vulnerability curves using an optimization routine known as genetic algorithm (David, 1998). First, an initial population of typically 100 random, monotonously increasing vulnerability curves is created. Each curve is defined at 21 supporting points covering the whole range of possible soil moisture deficits. Then, a damage simulation is performed for each curve and its fitness determined as the inverse root mean square error between simulated and observed damage. A subset of the 50 curves with the highest fitness is then selected, duplicated and slightly modified to form a new generation of vulnerability curves. Through iteration, the optimal vulnerability curve can thus be determined. This optimal curve is usually derived based on damage simulations covering the whole domain of France and the whole observation time period (1989-2002). Sensitivity experiments using only half of the time period lead to very similar results (see Sect. 5.2). Furthermore, using twice as many points for the description of the vulnerability curve or half as many does not result in a noticeable change of the simulation result.

Figure 3 shows the resulting optimal vulnerability curves for the CRU and E-obs meteorological data sets. Both curves show the same basic shape. The damage is zero for soil moisture deficits below a threshold of about $200 \mathrm{~mm}$. Above this threshold, the damage degree increases monotonously before leveling off at higher moisture deficits. The curves are thus highly non-linear.

\section{Results and Discussion}

\subsection{Simulation results for 1989-2002}

Simulated and observed building damages from soil subsidence are depicted in Fig. 4, Panel a. Observations are available for the time period 1989-2002 (Sect. 3.1), while the simulations using the two meteorological datasets are shown for the time period 1960-2002. In the period with overlap between the simulations and observations (1989-2002), the simulations agree well with the observed damage. While no observations are available prior to 1989, the much lower simulated mean damage and single peak in 1976 is in agreement with the qualitative observation that the only severe event of soil subsidence during this period occurred in 1976 (Salagnac, 2007).

Figure $4 \mathrm{~b}$ displays the distribution of observed and simulated damage for the time periods 1989-2002 and 19611990. Again, the observed and simulated damage distributions agree well for the period 1989-2002. The simulated distributions for the time periods 1989-2002 and 19611990 suggest that the level of damage has more than doubled in the observational period compared to the meteorological reference period (237 Mio Euro per year compared to ca. 115 Mio Euro per year, see also Table 1).

Two first conclusions can be drawn from these results. First, this analysis shows that within the studied region and for the considered time period soil moisture extremes and related building damages can be well captured with a model driven by meteorological input only. Second, we identify that a strong shift in soil moisture conditions has already taken place in France since the beginning of the 1990s, with much drier conditions than in the thirty preceding years. The 

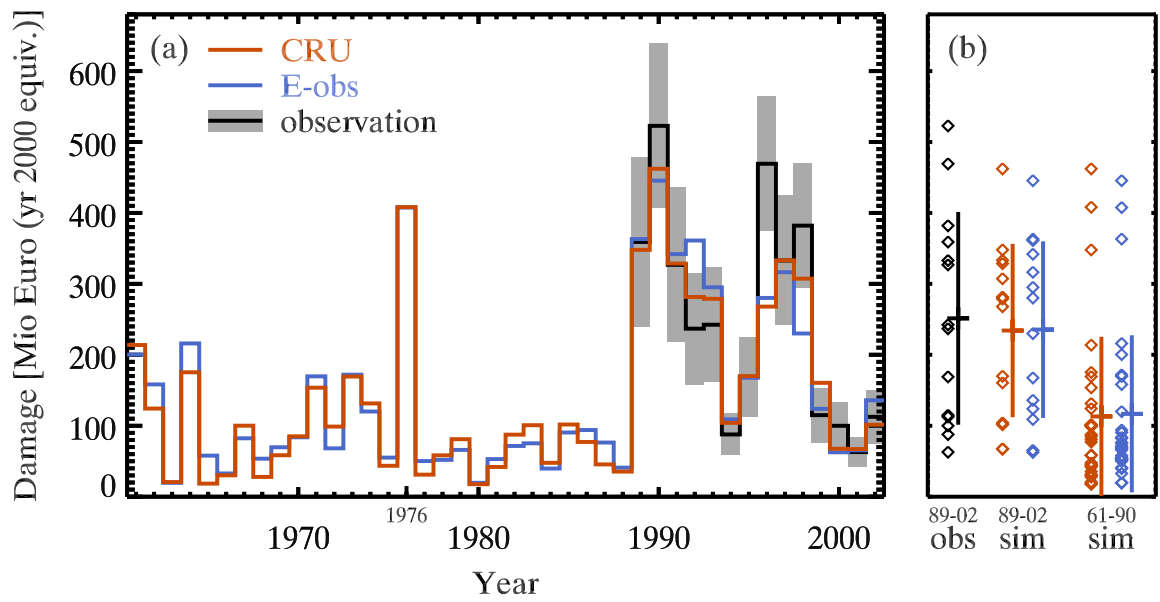

Fig. 4. (a) Damage time series from two simulations and observed damage with uncertainty range. (b) Comparison of observed (left) and simulated (center) damage distribution for observational period 1989 to 2002 in comparison to the reference period (right). Mean value and standard deviation are indicated by horizontal and vertical lines, respectively.
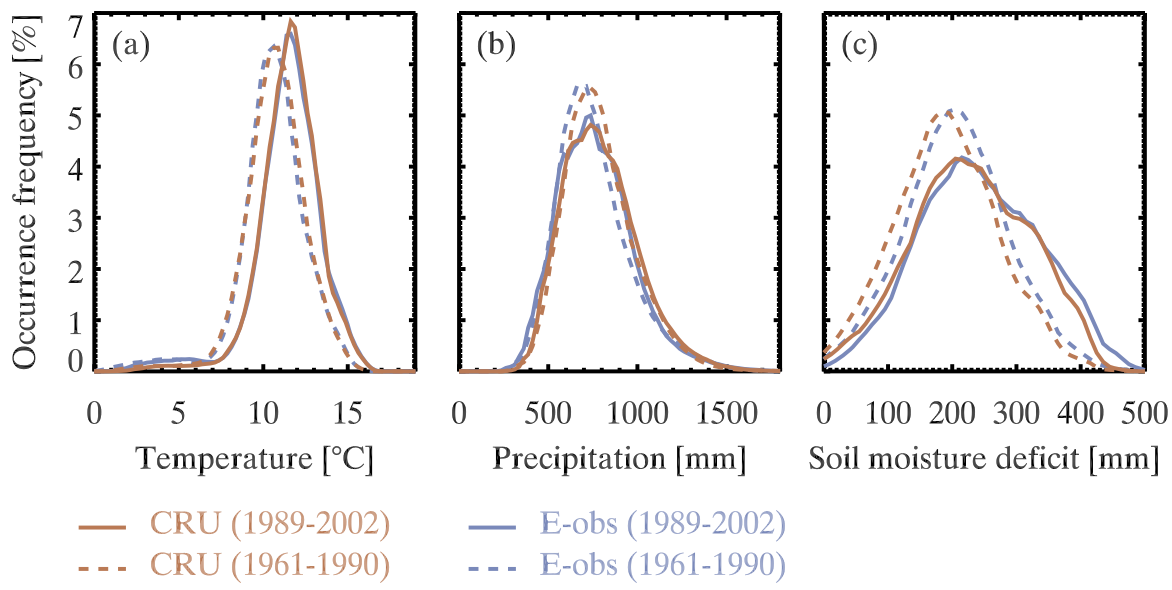

Fig. 5. Population weighted distribution of (a) annual mean temperature, (b) annual precipitation and (c) soil moisture deficit in percent per bin of $0.25^{\circ} \mathrm{C}, 25 \mathrm{~mm}$ precipitation and $10 \mathrm{~mm}$ moisture deficit, respectively.

drying trend is consistent with previous estimates of drought trends in Europe for the second half of the 20th century (Dai et al., 2004) and in line with climate-change projections for the 21st century for this region (Wang, 2005; Seneviratne et al., 2006b; Christensen et al., 2007).

The change in soil moisture conditions since 1989 in the simulation is mainly due to an increase of temperature within that period. This is illustrated in Fig. 5. Panel a shows the distribution of annual mean temperatures in France, weighted by population. The indicated percentages can thus be interpreted as the fraction of population living in areas with a certain mean temperature. It is clear from Fig. 5a that a distinct warming has occurred between the reference period of 1961-1990 (dashed lines) and the observation period 1989-
2002 (solid lines). This is true for both the CRU (red) and E-obs (blue) data set. This is quite contrary to the distribution of annual precipitation (Fig. 5b), which has apparently changed much less noticeably over the same time period. It can thus be concluded that the shift toward higher soil moisture deficits visible in Fig. $5 \mathrm{c}$ is a consequence of the increase in temperature and consequently additional evapotranspiration. Again, both data sets agree well.

The significance of Fig. $5 \mathrm{c}$ for the building damages becomes apparent when considered in combination with the vulnerability curves from Fig. 3. The vulnerability curves imply that no damage occurs for soil moisture deficits below about $200 \mathrm{~mm}$. Only the distribution above that threshold has therefore an influence on the amount of damage. Figure $5 \mathrm{c}$ 


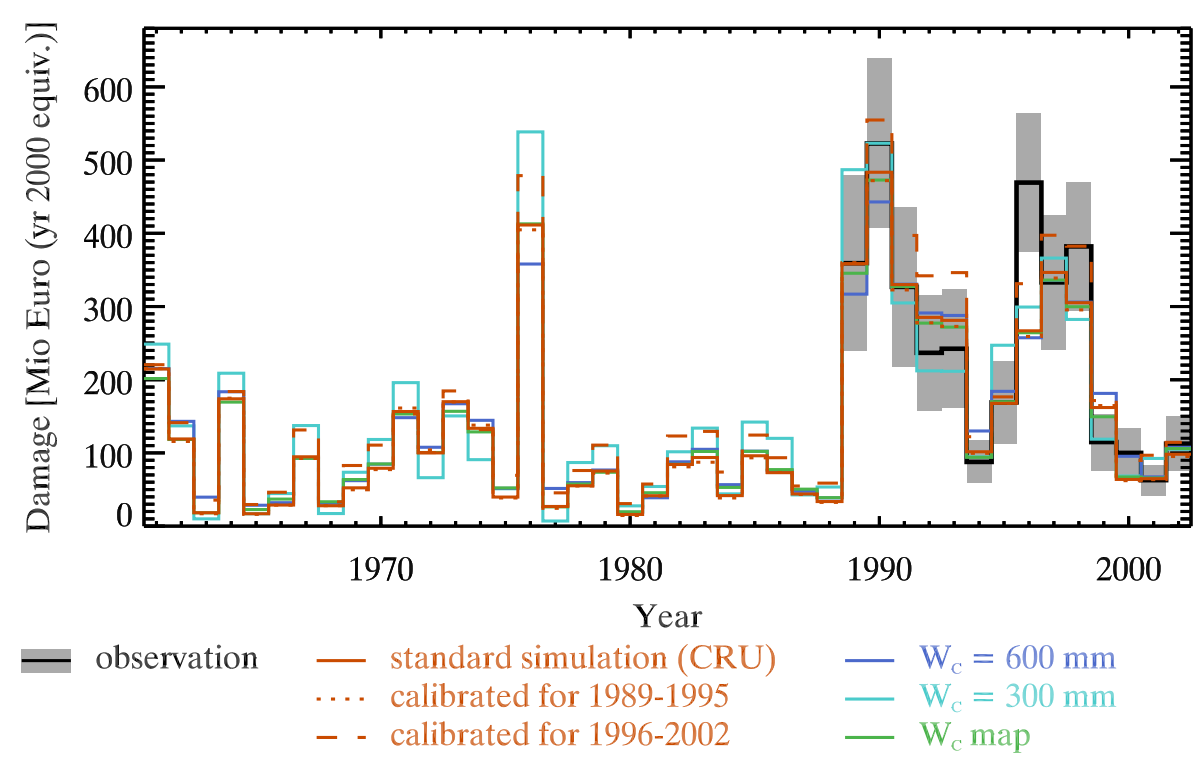

Fig. 6. Simulation results from a series of sensitivity experiments driven by the CRU meteorological observations, using only the first or second half of the available time period for calibration; changing the soil water holding capacity to 600 or $300 \mathrm{~mm}$ or specifying it according to a hydrological soil map.

Table 1. Observed and simulated damage due to drought-induced soil subsidence in Million Euros equivalent to year 2000 prices.

\begin{tabular}{cccc}
\hline Time period & Observation & $\begin{array}{c}\text { Simulation } \\
(\mathrm{CRU})\end{array}$ & $\begin{array}{c}\text { Simulation } \\
(\text { E-obs })\end{array}$ \\
\hline $1961-1990$ & - & 113 & 117 \\
$1989-2002$ & 251 & 234 & 236 \\
2003 & $1060^{\mathrm{a}}$ & - & 460 \\
\hline
\end{tabular}

${ }^{a}$ CCR estimate only.

shows that the occurrence of high soil moisture deficits has increased considerably in the observation period compared to the reference period.

It is thus the non-linearity of the vulnerability curve that has caused the distinct increase in building damages since 1989 , even though the changes in soil moisture conditions are moderate.

\subsection{Sensitivity experiments}

We have performed a series of sensitivity experiments to evaluate the robustness of our model. Results from these experiments are summarized in Fig. 6. First, we derived the vulnerability curve only from the first (red dashed) or second (red dotted) half of the damage observation period. This resulted in a slightly inferior simulation of the other half of the damage observation period, possibly caused by an incomplete adjustment of the time series to the reference year 2000 .
Then, we varied the soil water holding capacity from $300 \mathrm{~mm}$ (cyan) to $600 \mathrm{~mm}$ (blue), and by specifying it according to a hydrological soil map (green) (FAO, 1995). None of these changes altered the simulation results substantially, demonstrating the robustness of the model.

\subsection{Analysis for the 2003 European summer heat wave}

The European 2003 summer was characterized by an extreme heat wave and drought (Schär et al., 2004; Andersen et al., 2005; Ciais et al., 2005). This had dramatic impacts in terms of human health with about 15000 excess deaths in France alone (Haines et al., 2006). Moreover, unprecedented drought-induced subsidence damages were reported in that year, with an estimated insured loss of 1060 Mio Euro (in year 2000 equivalent) (CCR, 2007). Only one of the two meteorological datasets is available for 2003 (E-obs). A comparison of simulated damages using this meteorological dataset and the damage estimate in that year is provided in Table 1. Despite its good performance for the time period 1989-2002, the model underestimates the observed damage by a factor of 2.6 for 2003 . While this demonstrates limitations of our model, the poor performance may also be related to the uncommon drought pattern in 2003 compared to the previous years. Our model simulations suggest that during the reference period 1961-1990, the regular occurrence of soil moisture deficits above a critical level of $200 \mathrm{~mm}$ was confined to a limited number of regions (blue area in Fig. 7), where such soil moisture deficits occurred at least every second year on average. In 2003, the soil moisture deficit 
exceeded $200 \mathrm{~mm}$ in almost all of France (red area). Regions that were previously spared from soil subsidence were thus affected in 2003 for the first time. The analysis of reported damage costs with departmental resolution shows that these regions were more sensitive to soil subsidence, exhibiting higher damage per capita by about a factor of three in case of high soil moisture deficit compared to the other regions. This is possibly due to a lack of preparedness and adaptation. In addition, part of the damages reported in 2003 might originate from previous soil subsidence events. Such a damage accumulation is however only plausible in regions previously affected by soil subsidence. It can thus not explain the higher damage levels in regions first hit in 2003.

In analogy to the sequence of events in 2003, climate change may lead to enhanced risks of drought-induced soil subsidence in previously humid regions (Seneviratne et al., 2006b) which are thus not adapted to this hazard. This could result in very high levels of damage, even in an already near future (Seager et al., 2007). It is therefore crucial to determine which regions will be affected by droughts and soil subsidence with climate change. This is not only important for forecasting the potential level of future damage but also to plan preventive measures. It is clear from the 2003 case that such measures should not only be based on the experience of past damage but should anticipate possible changes in drought patterns associated with enhanced greenhouse warming.

\section{Conclusions and outlook}

Soil subsidence is a severe drought-associated hazard, which is expected to become of increasing concern in the future. It is thus important to develop predictive models that can allow us to assess such impacts in both present and future. In this study, we have demonstrated that building damages from soil subsidence in France can be well represented with a rather simple model driven by meteorological forcing only within the time period 1989-2002. This indicates a strong meteorological influence on the interannual variability in soil subsidence damages. Furthermore, our results reveal that the level of damage for the French domain has likely more than doubled in those years compared to the period 1961-1990. This is mostly a consequence of increased temperature since the 1990s, suggesting a link to climate change. Though the associated soil moisture depletion is relatively moderate, the large increase in damage is due to the non-linearity of the derived vulnerability curve.

The analysis of the extreme 2003 European shows however that the reported high level of damage in that year cannot be explained based on the employed model. This appears to be due to a higher sensitivity of the regions affected for the first time by soil subsidence in 2003, possibly as a consequence of lack of adaptation. In addition, part of the damages reported in 2003 might originate from previous soil

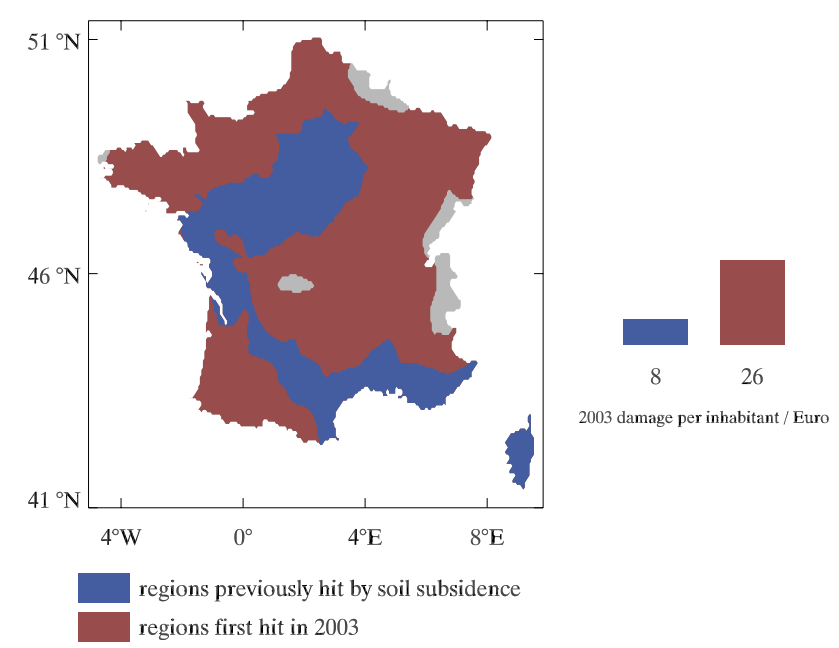

Fig. 7. Drought regions in France. Blue: Regions where simulated soil water deficits exceed $200 \mathrm{~mm}$ at least half of the years during the reference period (1961-1990), as well as in 2003. Red: Regions also affected in 2003, but not regularly during the reference period. Gray: Unaffected regions. The numbers on the right hand side represent estimated observed 2003 damage per capita for the blue and red regions.

subsidence events. Such a damage accumulation could however not explain the higher damage levels in regions first hit in 2003.

Future studies on soil subsidence should investigate to which extent adaptation or lack thereof can be included in a model framework. Moreover, it is possible that a better model performance is obtained by including further relevant components such as geological or land cover information. More detailed land surface models (e.g., Dirmeyer et al., 2006; Habets et al., 2008) configured for urban environments could also yield improved results. In addition, more accurate damage observations on a regional level are needed to validate the geographical distribution of soil subsidence damage simulations. More detailed damage data might also lead to a better understanding of the importance of damage accumulation. Finally, further investigations of the correlation between meteorology, soil moisture deficits and damages occurrence should be performed to further test the link between meteorology and soil subsidence. These analyses might also lead to the specification of vulnerability curves for soil subsidence.

Our study shows some first encouraging results for the simulation of drought-induced subsidence. The ability to correctly predict impacts of droughts, including those associated with soil subsidence is of high importance in the context of climate change. This is in particular the case due to the non-linearity in some of the responses and vulnerability functions. 
Acknowledgements. This study was conducted in the framework of the National Centre of Competence in Research (NCCR) Climate (http://www.nccr-climate.unibe.ch/) with funding from the Swiss Reinsurance Company and ETH Zurich. We acknowledge the E-obs dataset from the EU-FP6 project ENSEMBLES (http://www.ensembles-eu.org) and the data providers in the ECA\&D project (http://eca.knmi.nl). Population density data was obtained from the European Environment Agency Data Service at http://dataservice.eea.europa.eu/dataservice/.

Basin-Scale Water-Balance (BSWB) data is available at

http://www.iac.ethz.ch/data/water_balance/.

Edited by: A. Shamseldin

\section{References}

Andersen, O. B., Seneviratne, S. I., Hinderer, J., and Viterbo, P.: GRACE-derived terrestrial water storage depletion associated with the 2003 European heat wave, Geophys. Res. Lett., 32(4), L18405, doi:10.1029/2005GL023574, 2005.

Apel, H., Thieken, A. H., Merz, B., and Bloschl, G.: A probabilistic modelling system for assessing flood risks, Nat. Hazards, 38, 79100, 2006.

Boivin, P., Garnier, P., and Vauclin, M.: Modeling the soil shrinkage and water retention curves with the same equations, Soil Sci. Soc. Am. J., 70, 1082-1093, 2006.

Bronswijk, J. J. B.: Prediction of actual cracking and subsidence in clay soils, Soil Science, 148, 87-93, 1989.

CCR: Natural disasters in France, Caisse Centrale de Réassurance, Paris, 24 pp., 2007.

Christensen, J. H., Hewitson, B., Busuioc, A., Chen, A., Gao, X., Held, I., Jones, R., Kolli, R. K., Kwon, W. T., Laprise, R., Magana Rueda, V., Mearns, L., Menendez, C. G., Risnen, J., Rinke, A., Sarr, A., and Whetton, P.: Regional Climate Projections, in, Climate Change 2007: The Physical Science Basis. Contribution of Working Group I to the Fourth Assessment Report of the Intergovernmental Panel on Climate Change, edited by: Solomon, S., Qin, D., Manning, M., et al., Cambridge University Press, Cambridge, 2007.

Ciais, P., Reichstein, M., Viovy, N., Granier, A., Ogee, J., Allard, V., Aubinet, M., Buchmann, N., Bernhofer, C., Carrara, A., Chevallier, F., De Noblet, N., Friend, A. D., Friedlingstein, P., Grunwald, T., Heinesch, B., Keronen, P., Knohl, A., Krinner, G., Loustau, D., Manca, G., Matteucci, G., Miglietta, F., Ourcival, J. M., Papale, D., Pilegaard, K., Rambal, S., Seufert, G., Soussana, J. F., Sanz, M. J., Schulze, E. D., Vesala, T., and Valentini, R.: Europe-wide reduction in primary productivity caused by the heat and drought in 2003, Nature, 437, 529-533, 2005.

Crilly, M.: Analysis of a database of subsidence damage, Structural Survey, 19, 7-14, 2001.

Dai, A. G., Trenberth, K. E., and Qian, T. T.: A global dataset of Palmer Drought Severity Index for 1870-2002: Relationship with soil moisture and effects of surface warming, J. Hydrometeorol., 5, 1117-1130, 2004.

Dai, F. C., Lee, C. F., and Ngai, Y. Y.: Landslide risk assessment and management: an overview, Engineering Geology, 64, 65-87, 2002.

David, A. C.: An Introduction to Genetic Algorithms for Scientists and Engineers, World Scientific Publishing Co., Inc., p. 200,
1998.

Dirmeyer, P. A., Gao, X. A., Zhao, M., Guo, Z. C., Oki, T. K., and Hanasaki, N.: GSWP-2 - Multimodel anlysis and implications for our perception of the land surface, B. Am. Meteor. Soc., 87, 1381-1397, 2006.

Doornkamp, J. C.: Clay Shrinkage-Induced Subsidence, Geogr. J., 159, 196-202, 1993.

Dumas, P., Macaire, A., and Chavarot, A.: Mission d'enquete sur le regime d'indemnisation des victimes de catastrophes naturelles. rapport particulier sur les risques de subsidence dus a la secheresse, IGF-CGPC-IGE, Paris, 95 pp., 2005.

Dutta, D., Herath, S., and Musiakec, K.: A mathematical model for flood loss estimation, J. Hydrol., 277, 24-49, 2003.

Easterling, W. E., Aggarwal, P. K., Batima, P., Brander, K. M., Erda, L., Howden, S. M., Kirilenko, A., Morton, J., Soussana, J. F., Schmidhuber, J., and Tubiello, F. N.: Food, fibre and forest products, in, Climate Change 2007: The Physical Science Basis. Contribution of Working Group II to the Fourth Assessment Report of the Intergovernmental Panel on Climate Change, edited by: Parry, M. L., Canziani, O. F., Palutikof, J. P., et al., Cambridge University Press, Cambridge, 2007.

FAO: Digital Soil Map of the World and Derived Soil Properties, Food and Agriculture Organization of the United Nations, Rome, 1995.

Gao, X. J. and Giorgi, F.: Increased aridity in the Mediterranean region under greenhouse gas forcing estimated from high resolution simulations with a regional climate model, Global Planet. Change, 62, 195-209, 2008.

Habets, F., Boone, A., Champeaux, J. L., Etchevers, P., Franchisteguy, L., Leblois, E., Ledoux, E., Le Moigne, P., Martin, E., Morel, S., Noilhan, J., Segui, P. Q., Rousset-Regimbeau, F., and Viennot, P.: The SAFRAN-ISBA-MODCOU hydrometeorological model applied over France, J. Geophys. Res.-Atmos., 113, D06113, doi:10.1029/2007JD008548, 2008.

Haines, A., Kovats, R. S., Campbell-Lendrum, D., and Corvalan, C.: Climate change and human health: Impacts, vulnerability and public health, Public Health, 120, 585-596, 2006.

Haylock, M., Hofstra, N., Klein Tank, A., Klok, E., Jones, P., and New, M.: A European daily high-resolution gridded dataset of surface temperature and precipitation, J. Geophys. Res.-Atmos., 113, D20119, doi:10.1029/2008JD10201, 2008.

Hirschi, M., Seneviratne, S. I., and Schar, C.: Seasonal variations in terrestrial water storage for major midlatitude river basins, J. Hydrometeorol., 7, 39-60, 2006.

Klawa, M. and Ulbrich, U.: A model for the estimation of storm losses and the identification of severe winter storms in Germany, Nat. Hazards Earth Syst. Sci., 3, 725-732, 2003, http://www.nat-hazards-earth-syst-sci.net/3/725/2003/.

Milly, P. C. D., Betancourt, J., Falkenmark, M., Hirsch, R. M., Kundzewicz, Z. W., Lettenmaier, D. P., and Stouffer, R. J.: Climate change - Stationarity is dead: Whither water management?, Science, 319, 573-574, 2008.

Mitchell, T. D. and Jones, P. D.: An improved method of constructing a database of monthly climate observations and associated high-resolution grids, Int. J. Climatol., 25, 693-712, 2005.

Palmer, W. C.: Meteorological drought, Research Paper No. 45. US Weather Bureau: Washington DC., 1965.

Plante, S.: Subsidence case studies: using soil suction techniques, Structural Survey, 16, 141-145, 1998. 
Salagnac, J. L.: Lessons from the 2003 heat wave: a French perspective, Build. Res. Informat., 35, 450-457, 2007.

Schär, C., Vidale, P. L., Lüthi, D., Frei, C., Häberli, C., Liniger, M. A., and Appenzeller, C.: The role of increasing temperature variability in European summer heatwaves, Nature, 427, 332336, 2004.

Schindler, D. W. and Donahue, W. F.: An impending water crisis in Canada's western prairie provinces, Proceedings of the National Academy of Sciences of the United States of America, 103, 7210-7216, 2006.

Seager, R., Ting, M. F., Held, I., Kushnir, Y., Lu, J., Vecchi, G., Huang, H. P., Harnik, N., Leetmaa, A., Lau, N. C., Li, C. H., Velez, J., and Naik, N.: Model projections of an imminent transition to a more arid climate in southwestern North America, Science, 316, 1181-1184, 2007.

Seneviratne, S. I., Viterbo, P., Luthi, D., and Schar, C.: Inferring changes in terrestrial water storage using ERA-40 reanalysis data: The Mississippi River basin, J. Clim., 17, 2039-2057, 2004.

Seneviratne, S. I., Koster, R. D., Guo, Z. C., Dirmeyer, P. A., Kowalczyk, E., Lawrence, D., Liu, P., Lu, C. H., Mocko, D., Oleson, K. W., and Verseghy, D.: Soil moisture memory in AGCM simulations: Analysis of global land-atmosphere coupling experiment (GLACE) data, J. Hydrometeorol., 7, 1090-1112, 2006a.
Seneviratne, S. I., Lüthi, D., Litschi, M., and Schär, C.: Landatmosphere coupling and climate change in Europe, Nature, 443, 205-209, 2006b.

Sheffield, J. and Wood, E. F.: Projected changes in drought occurrence under future global warming from multi-model, multiscenario, IPCC AR4 simulations, Clim. Dynam., 31, 79-105, 2008.

Thornthwaite, C. W.: An approach toward a rational classification of climate, Geogr. Rev., 38, 55-94, 1948.

Trenberth, K., Jones, P., Ambenje, P., Bojariu, R., Easterling, D., Klein Tank, A., Parker, D., Rahimzadeh, F., Renwick, J., Rusticucci, M., Soden, B., and Zhai, P.: Observations: Surface and Atmospheric Climate Change, in, Climate Change 2007: The Physical Science Basis. Contribution of Working Group I to the Fourth Assessment Report of the Intergovernmental Panel on Climate Change, edited by: Solomon, S., Qin, D., Manning, M., et al., Cambridge University Press, Cambridge, 2007.

Wang, G. L.: Agricultural drought in a future climate: results from 15 global climate models participating in the IPCC 4th assessment, Clim. Dynam., 25, 739-753, 2005.

Weber, L. and Nkemdirim, L.: Palmer's drought indices revisited, Geografiska Annaler Series a-Physical Geography, 80A, 153172, 1998. 